\title{
BORDER CROSSINGS THROUGH THE EYES OF A FEMALE NARRATOR: CONCEPT BORDER IN LAURA INGALLS WILDER'S LITERARY DISCOURSE
}

\author{
Halyna Zaporozhets \\ https://orcid.org/0000-0002-2086-7942 \\ halyna.zaporozhets@chmnu.edu.ua \\ Petro Mohyla Black Sea National University, Ukraine \\ Yuliya Stodolinska \\ https://orcid.org/0000-0002-4515-0323 \\ yuliia.stodolinska@chmnu.edu.ua \\ Petro Mohyla Black Sea National University, Ukraine
}

Received January 13, 2021; Revised April 8, 2021; Accepted May 2, 2021

\begin{abstract}
Many recent studies have focused on the depiction of BORDER from the point of view of cognitive linguistics, gender studies, cultural studies. However, little research has been undertaken to study the books for children that address questions of borderlands, territorial and metaphorical borders in historical and modern fiction among which is Laura Ingalls Wilder's Little House Series. The objective of this article is to study the portrayal of cultural concept BORDER from the perspective of a female child narrator in Laura Ingalls Wilder's literary discourse, focusing on the depiction of territorial and metaphorical borders in order to establish the possible influences and interrelations. The multidisciplinary approach that combines the methods and former research findings of such disciplines as cognitive linguistics, psycholinguistics, border studies, discourse studies is implemented to determine the narrator model and the peculiarities of psychonarration in the book series; classify concept BORDER from the point of view of cognitive linguistics and restructure its components; provide an analysis of the figurative and associative layer of the cultural concept BORDER and examine the role of the verbalization of feelings and emotions in the portrayal of territorial and metaphorical border crossings in Wilder's books. Overall, it is assumed that the female child narrator has been chosen by the author based on the psychological peculiarities of the target audience of the books. The results indicate that the combination of the external and internal forms of psychonarration ensures a clearer portrayal of the female perception of border crossings in the analyzed discourse. The territorial and metaphorical borders depicted in Wilder's works are interwoven and influenced by historical, biographical, gender, and psychological peculiarities.
\end{abstract}

Keywords: child-narrator, concept BORDER, female narrator, literary discourse, metaphorical borders, psychonarration, territorial borders.

Запорожець Галина, Стодолінська Юлія. Перетини кордонів очима жінки-наратора: концепт КОРДОН у літературному дискурсі Лори Інглз Вайлдер.

Анотація. Останнім часом 3'являється дедалі більше наукових розвідок у галузі когнітивної лінгвістики, гендерних та культурних студій, які присвячено дослідженню актуалізації кордонів. Однак дитячі книги, що висвітлюють питання прикордонних

(C) Zaporozhets, Halyna; Stodolinska, Yuliya, 2021. This is an Open Access article distributed under the terms and conditions of the Creative Commons Attribution 4.0 International Licence (http://creativecommons.org/licenses/by/4.0).

East European Journal of Psycholinguistics, 8(1), 125-136. https://doi.org/10.29038/eejpl.2021.8.1.zap 
територій, територіальних і метафоричних кордонів в історичній та сучасній художній літературі, серед яких серія книжок для дітей відомої американської письменниці Лори Інглз Вайлдер «Маленький будинок», ще мало досліджені. Метою статті $є$ аналіз репрезентації культурного концепту КОРДОН з точки зору дитини-наратора (дівчинки) в американському літературному дискурсі Лори Інглз Вайлдер, зосереджуючись на відтворенні територіальних i метафоричних кордонів для встановлення можливих взаємовпливів. Міждисциплінарний підхід поєднує методи та попередні надбання вітчизняних та зарубіжних науковців галузей когнітивної лінгвістики, психолінгвістики, прикордонних студій, дискурсології для того, щоб визначити роль обраної моделі наратора та особливості психонаративу у досліджуваних творах американської письменниці, класифікувати концепт КОРДОН та реструктурувати його компоненти, проаналізувати образно-асоціативний шар культурного концепту КОРДОН та дослідити роль вербалізації почуттів та емоцій у розкритті особливостей зображення перетинів територіальних i метафоричних кордонів у творах Лори Інглз Вайлдер. Загалом, вважаємо, що дитину-наратора (дівчинку) обрано авторкою на основі психологічних особливостей цільової аудиторії книжок. Результати дослідження свідчать про те, що поєднання зовнішньої та внутрішньої форми психонаративу забезпечує чіткіше зображення жіночого сприйняття перетину кордонів у аналізованому літературному дискурсі. Територіальні та метафоричні кордони, репрезентовані у творах Лори Інглз Вайлдер тісно переплітаються та залежать від історичних, біографічних, гендерних та психологічних особливостей.

Ключові слова: дитина-наратор, жінка-наратор, концепт КОРДОН, літературний дискурс, метафоричні кордони, психонаратив, територіальні кордони.

\section{Introduction}

At all times of its existence the USA has been the country of borderlands, encompassing not only territorial borders between states, territories, neighboring countries but also cultural borders which are created or influenced by territorial borders and vice versa. The American literary discourse encompasses numerous works where the question of border crossings comes into play and children's literature is not an exception. Books for children address the questions of borderlands, territorial and metaphorical borders in historical and modern fiction. The attention of specialists in contemporary literary, cultural, and psycholinguistic studies in North America and beyond has turned to these books once again making an attempt to "reread" them as a number of rather controversial topics, such as gender and racial issues are triggered (Clasen \& Hassel, 2019; Zanfabro, 2017).

Laura Ingalls Wilder's Little House Series books, written from a female perspective, have been famous among readers from the date of publication and continually draw the attention of experts in Gender and Literature studies. Researchers have mostly focused on the correlations of the author's and the main character's biographies. Thus, Ketcham (2015) tries to define the place of Wilder's works in historical context. Maher (1994) compares and contrasts the borderlands depicted in Laura Ingalls Wilder's and Caddie Woodlawn's books. Romines (1997) studies the content of the novels and the process of their creation from an interdisciplinary perspective, gender and cultural studies in particular. However, concept BORDER in Laura Ingalls Wilder's literary discourse has not yet been studied from a linguocultural, cognitive, and psycholinguistic perspective. 


\section{Methods}

The aim of this article is to study the portrayal of the concept BORDER from the perspective of a female child narrator in Laura Ingalls Wilder's literary discourse, focusing on the depiction of territorial and metaphorical borders in order to establish the possible influences and interrelations between them. The subject of analysis is the Little House book series and the object is the specifications of territorial and metaphorical borders' portrayal in the works of the author depicted by the female narrator. The novels of the Little House Series are the material for research.

The first part of the article investigates the narrator model chosen by Laura Ingalls Wilder as one of the participants of the literary discourse and the peculiarities of psychonarration in the book series. The second part focuses on classifying the concept BORDER from the point of view of Cognitive Linguistics and restructuring its components. The third part provides a study of the figurative and associative layer of the cultural concept BORDER as well as the analysis of the role of the depiction of feelings and emotions in the portrayal of territorial and metaphorical border crossings in Wilder's books.

Methodology of the research, which is grounded on the aim, requires an integrative multidisciplinary approach that combines the methods and former research findings of such disciplines as cognitive linguistics (principles of interconnection of language and cognition (Bieliekhova et al, 2018; Kubriakova 2002), reconstruction of cultural concepts based on language data (Karasik et al, 2005)), psycholinguistics (the study of psycholinguistic processes in the broad context of thought and communication, necessity of simultaneous analysis of linguistic and psychological information (Ahrens, 2012; Bruner, 1975; Wertsch, 2009), gender aspects of concepts in discourses and narrations (Petiak, 2020; Stampino, 2014; Wall, 1994), the study of language as active and purposeful language activity (Bergen, 2012; Vygotskyi, 1996)), border studies (correlation of the notions of borders, borderlands, borderscapes (Brambilla, Laine, Scott, \& Bocchi, 2017; Fellner, 2009; Schimanski, 2019; Wille, 2016)), discourse studies (theory of discourse as a cognitive and communicative phenomenon (Bondarenko, Martynyuk, Frolova, \& Shevchenko, 2017; Gee \& Handford, 2014; Prikhodko, 2013)).

As part of the psycholinguistic approach, in this research discourse is viewed as a complex communicative phenomenon which encompasses the social context, information about the discourse participants and the knowledge about the processes of text production and perception. Descriptive discourse analysis is applied to establish the psychological context and the components of the analyzed discourse, the author's intentions. Cognitive analysis was employed to classify the cultural concept BORDER in the literary discourse based on its structural-semantic, communicative-pragmatic, cognitive-semantic properties. Methods and procedures for conceptual and cognitive-semantic analysis were used to establish the components and linguocultural peculiarities of the analyzed concept. Peculiarities of 
psychonarration in the analyzed book series are determined through the analysis of lingual and narrative means of the representation of different events from the life of the characters which actualize the emotional and psychological state of the characters and represent their attitudes and feelings about different types of borders.

\section{Results and Discussion}

\section{The role of the female child-narrator in Laura Ingalls Wilder's literary discourse}

Literary discourse is viewed as the discourse of fiction literature, which is characterized by the presence of anthropological and ideological factors influencing the formation of the reader's opinion (Perelomova, 2008, p. 81). An important feature of literary discourse is its pragmatic essence and the communication model author - literary work - reader. American literary discourse is a written type of discourse. It is considered to be an unaddressed discourse, aimed at a potential generalized addressee, not a specific person. The psychological and communicative contexts encompass such components of discourse as discourse participants, their communicative competence, aim, strategies, tactics, channel of communication (Karasik, 2007). Thus, the participants of the analyzed discourse are the author and the readers. The channels of communication are the books of the series. The author's main aim is to depict the life of pioneers in the 1870s-1880s as realistically as possible. She also strives to involve her readers in the process of analyzing the events and people's feelings described.

As children are the main target audience of the books, it is vital to understand psychological peculiarities of children's minds when choosing a narrator. In Psychology it is often claimed that men and women see the world differently: women tend to be more emotional and are attentive to detail (Baron-Cohen, 2004; Helgeson, 2020). Similarly, adults and children also see and percept the world differently - their worldviews are characterized by rather distinctive peculiarities (Lepskaya, 1997; Lust, 2011; Siegler, Eisenberg, Gershoff, Saffran, \& Leaper, 2020). Psychological peculiarities of the communication models adult-child and child-child have been studied less than adult-adult. The communication model adult-child consists of four aspects: content, emotional, factual and linguodidactic (Lepskaya, 1997, p. 7). Since the child usually has insignificant communicative competence, the adult helps the child understand what is going on, how to behave and teaches the child to react appropriately in different situations. Wilder chooses a female child-narrator for her books. Her intention was to construct the model childchild in her books and to exclude the linguodidactic aspect so that the narrator and the reader are on the same level.

Among the different types of narrators, a peripheral and a third-person narrator should be distinguished. A third-person narrator is: "intrusive narrator who not only reports, but also comments on and evaluates the actions and motives of 
the characters, and sometimes expresses personal views about human life in general" (Abrams \& Harpham, 2015, p. 272). The peripheral narrator, on the other hand, just presents the facts, letting the readers make their own conclusions about the feelings and emotions of the protagonists (Abrams \& Harpham, 2015, p. 275). The female child narrator and the main character in Wilder's books are supposedly different people, however, they are often perceived as a whole. Taking into consideration the proximity of the female narrator to the protagonist, the description and evaluation of the situations and feelings, it can be assumed that the author has chosen a third-person female narrator for the books, yet, leaving enough space for the audience to ponder over and judge the actions of the fictional characters.

In her works, Wilder draws on different means of psychological depiction of characters and events, which reinforces the psychologism of her works and leads us to the importance of elements of psychonarration in the Little House books. Psychonarration is the portrayal of psychological and emotional states of the character, thus, reflecting the author's assessment of reality (Izotova, 2015, p. 45). Cohn distinguishes consonant ("the narrator cannot be grasped as a separate entity within the text" (Cohn, 2011, p. 30)) and dissonant ("narrator even as he focuses intently on an individual psyche, remains emphatically distanced from the consciousness he narrates") psychonarration (Cohn, 2011, p. 26). Wilder uses consonant psychonarration because the thoughts and feeling of the main character are portrayed without being criticized or denied. The combination of external (verbal portrayal of external expressions of different emotional states of the characters, i.e. mimics, gestures, etc.) and internal (depiction of character's emotions and feelings through self-description, i.e. inner monologue, dreams, etc.) forms of psychonarration (Izotova, 2015, p. 46) in the Little House books ensures a clearer portrayal of the individual's inner experience and their attitude to different types of borders depicted in the book series.

Thus, the choice of the female child-narrator is supposedly dictated by the wish to make the books understandable and close to the child readers and attractive for the adults. The child's perception of the world (especially that of a girl) which is considered to be fresh, attentive to detail and very sincere is portrayed verbally through the elements of psychonarration in the analyzed discourse and encourages the readers to trust the female child-narrator.

\section{The classification and structure of the concept BORDER}

The problem of concept classification has been researched by different scholars, among whom are Karasik, Prikhodko, Vorkachov to name a few. Prikhodko differentiates monodiscursive and polydiscursive concepts based on the actualization of a concept in one or several discourses accordingly (Prikhodko, 2013). Cognitive and discourse analysis made it possible to determine that the polydiscursive cultural concept BORDER is one of the central concepts in the analyzed American literary discourse. It is not limited to one particular discourse and can be actualized in different discourses (political, business, literary, etc.). 
Karasik suggests classifying concepts based on their structural and semantic, cognitive and semantic, communicative and pragmatic properties (Karasik, 2007). According to its structural and semantic properties concept BORDER is considered to be a parametric concept (can have quantitative or qualitative indicators and may have both an abstract and material objectification). In terms of cognitive semantics concept BORDER is a universal concept (supranational character and worldwide significance although some properties may be limited to a certain nation or culture). Taking into consideration the communicative and pragmatic properties of the analyzed concept and the fact that it is a mental construct, which is associated with certain guidance characteristics, norms of behavior concept BORDER is classified as a regulatory concept.

Concepts are coded through language, thus, in order to portray the mental model of the concept it is appropriate to analyze their linguistic representation. The structure of the analyzed concept consists of the logical and notional as well as the figurative and associative layers. The analysis of the definitions given in the dictionaries shows that concept BORDER is revealed in two main subcategories: BORDER as a line, edge between something and BORDER as an area or part near the separating line (COD; MWOD). The common semantic features of the concept which are traced both in lexicographic sources and the concept realization in the analyzed discourse construct the core of logical and notional layer. These are the lexemes which represent the land in between two territories. All other characteristics do not have a universal character and are part of the periphery. These are the lexemes which encompass the divisional feature.

The figurative and associative layer encompasses the knowledge, images, and associations relevant to the concept. Domains Territory, Society, Culture enable the comprehension of the cultural concept BORDER through the eyes of a female narrator. The slots of these domains are filled with nominative units which identify territorial and metaphorical borders. Such nominative and attributive characteristics as territorial peculiarities, age, gender, social roles, cultural norms which are expressed by different parts of speech, contribute to a more detailed presentation of borders.

\section{Territorial and metaphorical borders in Laura Ingalls Wilder's literary discourse}

Semantic analysis of the means of verbalization of each conceptual layer indicates that they are used to represent the variety of territorial and metaphorical borders depicted in the analyzed discourse. As the territorial and metaphorical borders are depicted from the point of view of a female child narrator it is also important to analyze the elements of psychonarration in the books which portray the verbal descriptions of feelings, emotions, inner monologues relevant to the perception of different borders. 


\section{Territorial borders}

Territorial borders are portrayed from the female point of view in all of the books of the series and can be classified into state/territory, natural, and physical borders. These borders can be interchangeable and can substitute or supplement one another.

As the Ingalls family changes their place of living they travel for hundreds of miles and go from one state or territory to another. The borders between different states are often present only on the maps and official documents without any physical representation.

The natural borders are different in the books of the series and are presented through type of land (i.e. wood, prairie), geographic component (i.e. state, rural place, town). In each story the life of the family is described in a place which is the borderland itself, a certain periphery, or the place that is subject to certain natural borders (often the border between the world that is known to the family, already investigated by them, the so-called civilization and the world that is unknown and not yet explored, wild territory which needs to be settled).

As the story unveils, territorial borders become more obvious and much narrower. The vast and almost empty prairie land that was home to the Ingalls family is replaced with the buildings in the town that become the new home for the characters. During the life on the prairie Laura enjoys spending time outside where no borderline can be seen for miles ahead. She seems quite happy there which can be assumed from the verbal descriptions of the feelings of joy, happiness, and content (she was smiling, Laura felt all excited at once (Wilder, 2003d, p.12), felt free and independent and comfortable together (Wilder, 2003c, p.101)) caused by freedom and proximity to nature. A lot of the borders on the prairie are rather relative.

The life in the city has much more restricted space, both the town has its territorial limits and personal space is not so broad and unlimited as before. As the borders in the city become more evident, the verbal portrayals of happiness are substituted with the portrayals of fear and insecurity (scared (Wilder, 2003e, p.65), she felt small and frightened ... she could hardly breathe (Wilder, 2003g, p.87), ... had never felt such a stillness. It was not the happy stillness of the prairie ... felt it in the very pit of her stomach (Wilder, 2003e, p.92)). Based on completely different descriptions of the feelings when living close to nature and when moving to town, it may be assumed that the territorial borders were extremely vivid for the characters and influenced their lives greatly.

Physical borders are portrayed as fences, walls, doors which set the dividing line between the properties of different people. Each time the family moves, Laura's father makes sure that they have their own house where thick walls are a border not only for natural phenomena but also for the visitors. The doors represent a revolving border - closed when visitors are unwanted and open when they are welcome. The glass windows become a transparent border - the glass protects from rain, snow, different insects, etc. but at the same time you can look straight through it and see 
the endless prairie land that lies beyond. Overall, the natural and physical borders have a rather significant impact on the lives of the characters, their ways of life, feelings, and emotional state.

\section{Metaphorical borders}

The portrayal of borders in the novels is not limited to territorial borders. Certain metaphorical borders are depicted as well: the borders that arise in our cognition, the ones that often cannot be seen or explained but can be vividly felt. They are classified into personal and cultural.

The personal borders are based on age, gender, and social role differentiation. The opposition of the child and adult world where age is the border is vividly portrayed by the female child narrator in the presentation of Laura's life. When little Laura feels fantastic (it felt so pleasant, and Laura felt so happy and good that no one would ever have thought she could be as naughty as she was that evening (Wilder, 2003c, p. 44)) and wants her parents to run around and have fun with her, she is told that they are not supposed to do so because of the age (they were too grown-up to show surprise. A grown-up person must never let feelings be shown by voice or manner (Wilder, 2003c, p. 45)). It is hard for Laura to understand these limitations, to find the line that separates the two worlds at first. However, when she becomes an adult herself (felt then that she was not a little girl any more, must behave like a grown-up (Wilder, 2003f, p. 28)), she is the one who draws the border line between herself and her younger siblings (Laura felt like crying, but of course she didn't. Only little babies cried (Wilder, 2003f, p. 30)). She is the one who says that she is an adult and has to work and earn money instead of having fun with them (Wilder, 2003a, 2003f, 2003g). The age as a border limits actions, perceptions and feelings, implies certain responsibilities and restrictions for different age groups.

The gender principle influences personal borders in the story even stronger, it is the foundation of the division of roles and chores in the family. Wilder's books present Laura as the pioneer girl who attempts to break the traditional stereotypes, to move away from a strict division of activities based on the gender principle. Instead of spending time sewing and cooking, Laura prefers to spend time with her father and learn from him (Wilder, 2003d, p. 69). Laura is described as more reserved and afraid to show her feelings when she is around her mom (she feels she must do it to please Ma, she would always be scared and she must never show it (Wilder, 2003g, p. 56)). However, when Laura is around her father, she feels more confident, more at ease (felt so happy running around the prairie barefoot while $\mathrm{Pa}$ was watching (Wilder, 2003d, p. 34), Pa understood how she felt (Wilder, 2003g, p. 47)). The main character is strongly identified with $\mathrm{Pa}$. She is stronger, more courageous than the other female characters, she is willing to take risks and overcome obstacles. Wilder shows how the women's roles are redefined and how personal gender borders begin to shift. As Maher claims, the female characters "cross personal borders into a redefined female space" (Maher, 1994, p.1 35). 
American West is often defined as a cultural crossroads, a space defined by ever-shifting borders. The cultural borders are often directly connected to territorial borders and arise when the representatives of different cultures meet and live, especially on the borderlands. The little girl Laura faces the cultural differences when communicating with the Osage neighbors (some of whom were French), with the Scotts, Norwegians, Russians, etc. All the problems and challenges that the family comes across are portrayed through the eyes of a girl showing feelings of fear and insecurity at first which later on are replaced with confidence and trust. This is done to persuade the readers, both children and adults, that intercultural communication is rather important and to encourage them to learn new things as the children absorb new knowledge rather rapidly in their childhood. This approach promotes the acceptance of other cultures.

\section{Interrelation of territorial and metaphorical borders}

Romines emphasizes that the author of the Little House book series "began to propose some of the hardest and most persistent questions for an emigrant nation: questions of possible cultural interaction, cultural collision and a potentially multicultural life" (Romines, 1997, p.75). The most controversial episodes are portrayed in the book Little House on the Prairie when the family goes West into Kansas, which was considered to be the Indian Territory. In the novel, the comprehension of territorial borders by the main characters and their attitudes to them are impacted by the personal borders that evolve. $\mathrm{Pa}$, who has the social role of the head of the family, at first, violates territorial borders of the Indian land. His attitude changes and, at a certain point, he acknowledges the Indian's right for the land and surrenders. Ma, according to the social norms, completely obeys her husband and the question of territorial borders is not an exception. Laura's difficult questions probe the viewpoints both of $\mathrm{Ma}$ and $\mathrm{Pa}$. The female child narrator describes the diverse feelings and emotions of the characters in an attempt to depict how the age and gender borders prevent the characters from listening to each other and from exchanging the information.

No direct communication is seen in the episode with the Indians and the actions of the characters are often determined by certain personal assumptions, stereotypes, ideas, and beliefs. The Indians, on the one hand, according to their cultural norms and beliefs, try to preserve their territory. The Americans, on the other hand, are assured in their superiority and their right for the land which they consider to be unsettled. This is the vivid illustration of the violation of existing territorial borders combined with the existence of personal and cultural borders which resulted in misunderstandings and a significant culture clash.

Thus, the territorial borders as well as the metaphorical ones in the novels analyzed are constantly shifting as the Ingalls family moves West and gets acquainted with representatives of other cultures and nationalities. The verbal representation of different feelings shows the change of attitude to the representatives of different cultures and how the cultural borders may become more 
or less significant depending on the character's individual experience and perception.

\section{Conclusions}

Overall, the analyzed literary discourse is a written discourse, the main participants of which are the author and the readers, the channel of communication the books of the Little House Series. Wilder has chosen the female child-narrator based on the psychological peculiarities of the target audience of the books children. Her intention was to depict the events realistically, involve readers in the process of event analysis, construct the model child-child, and to exclude the linguodidactic aspect so that the narrator and the reader are on the same level. The female narration strategy is seen in the combination of providing the factual description of the events taking place and letting the readers make their own judgements or offering elaborate portrayals of the actions and the feelings of the characters of the story. Wilder draws on different means of psychological depiction of characters and events, which reinforces the psychologism of her works and emphasizes the importance of elements of psychonarration in the Little House books. The female child-narrator's role is seen in depicting the interrelation of various borders, the so-called border crossings, by providing their detailed, accurate, and often emotional portrayal which is often original due to age and gender.

The integrative approach employed in the research has led to the conclusion that the concept BORDER is a parametric universal regulatory cultural concept. Its linguistic, cognitive, and semantic characteristics structure a new viewpoint on the female perception of border crossings in the literary discourse. The territorial and metaphorical borders depicted in Wilder's works are interwoven and influenced by historical, biographical, gender, and psychological peculiarities. The combination of the external and internal forms of psychonarration in the Little House books ensures a clearer portrayal of the female's inner experience and attitude to different types of borders depicted in the book series. Territorial borders cannot be studied separately because territorial border crossings raise a number of questions closely connected with personal and cultural borders. Only a complex analysis can reveal the interconnections of the borders and their mutual influence.

\section{References}

Abrams, M. H. \& Harpham, G. G. (2015). A glossary of literary terms. Stamford: Cengage Learning. Ahrens, K. (2012). Finding what you expect to see: Theoretical modeling in Psycholinguistics. Journal of Social Sciences, 8(3), 372-380. https://doi.org/10.3844/jssp.2012.372.380

Baron-Cohen, S. (2004). The essential difference the truth about the male and female brain. New York, NY: Basic Books.

Bergen, B. K. (2012). Louder than words: The new science of how the mind makes meaning. New York: Basic Books. 
Bieliekhova, L., Volkova, S., Marina, O., Tsapiv, A., et al. (2018). Linhvokohnityvna poetolohiia: kolektyvna monohrafiia [Linguocognitive poetology: collective monograph]. Kherson: Helvetyka.

Bondarenko, Ye., Martynyuk, A., Frolova, I., \& Shevchenko, I. (2017). Kak narisovat portriet ptitsy: mietodolohiia kohnitivno-kommunikativnoho analiza yazyka: kol. monohrafiia [How to draw the portrait of a bird: methodology of cognitive and communicative analysis of language: collective monograph]. Kharkiv: V. Karazin Kharkiv National University.

Brambilla, C., Laine, J., Scott, J., \& Bocchi, G. (2017). Borderscaping: Imaginations and practices of border making. London: Routledge, Taylor \& Francis Group.

Bruner, J. (1974). From communication to language - a psychological perspective. Cognition, 3(3), 255-287. https://doi.org/10.1016/0010-0277(74)90012-2

Clasen, T. \& Hassel, H. (2019). Gender(ed) identities: Critical rereadings of gender in children's and young adult literature. London: Routledge.

Cohn, D. (2011). Transparent minds: Narrative modes for presenting consciousness in fiction. Princeton (N.J.): Princeton University Press.

Fellner, A. (2009). Transhemispheric visions, border studies and the literatures of the Americas. In D. Steiner \& S. Danner (Eds.). Exploring Spaces: Practices and Perspectives (pp. 251-277). Wien: LIT Verlag.

Gee, J. P. \& Handford, M. (2014). The Routledge handbook of discourse analysis. London: Routledge. Helgeson, V. S. (2020). The psychology of gender. New York: Routledge, Taylor \& Francis Group. Izotova, N.P. (2015). Lingvistika psihonarrativa v romanah J. M. Coetzee: parametry izucheniya [Linguistics of psychonarration in J. M. Coetzee's novels: aspects of study]. Science and Education a New Dimension. Philology, 3(44), 45-49.

Karasik, V. I. (2007). Yazykovyye klyuchi [Language Keys]. Volgograd: Paradigma.

Karasik, V., Prokhvacheva, O., Zubkova, Ya., \& Hrabarova, E. (2005). Inaia mientalnost. [Other Mentality]. Moscow: Gnozis.

Kubriakova, Ye. (2002). O sovriemiennom ponimanii termina "kontsept" v linhvistikie i kulturolohii. [On the contemporary understanding of the term "Concept" in Linguistics and Cultural Studies]. Riealnost, Yazyk i Soznaniie, 2, 5-15.

Ketcham, S. (2015). Laura Ingalls Wilder: American writer on the prairie. New York: Routledge. Lepskaya, N. I. (1997). Yazyk rebenka (Ontogenez rechevoy kommunikatsii) [Child's language (Ontogenesis of speech communication)]. Moscow: MTU.

Lust, B. (2011). Child language: Acquisition and growth. Cambridge: Cambridge University Press.

Maher, S. N. (1994). Laura Ingalls and Caddie Woodlawn: Daughters of a border space. The Lion and the Unicorn, 18(2), 130-142. https://doi.org/10.1353/uni.0.0141

Perelomova, O. S. (2008). Linhvokul'turni kody intertekstual'nosti ukrayins'koho khudozhn'oho dyskursu: diakhronichnyy aspect [Linguocultural code of intertextuality of Ukrainian literary discourse: diachronic aspect]. Sumy: Sumy State University.

Petiak, O. (2020). Associative and Gender Aspects of the Emotional Concept of Jealousy in the Ukrainian Linguistic Culture. East European Journal of Psycholinguistics, 7(1). https://doi.org/10.29038/eejpl.2020.7.1.pet

Prikhodko, A. (2013). Kontsepty i kontseptosistiemy [Concepts and systems of concepts]. Dnipropetrovsk: Bielaia Ye.A.

Romines, A. (1997). Constructing the Little house: Gender, culture, and Laura Ingalls Wilder. Amherst, MA: University of Massachusetts Press.

Schimanski, J. (2019). Border aesthetics: Concepts and intersections. New York: Berghahn.

Siegler, R. S., Eisenberg, N., Gershoff, E. T., Saffran, J., \& Leaper, C. (2020). How children develop. New York, NY: Worth, Macmillan Learning.

Stampino, M. G. (2014). The Woman Narrator's Voice: The Case of Lucrezia Marinella's Enrico. Italian Studies, 69(1), 75-94. https://doi.org/10.1179/0075163413z.00000000060 
Vygotsky, L. S. (1996). Myshleniye i rech' [Thought and speech]. Moscow: Labirint.

Wall, B. (1994). The narrator's voice: The dilemma of children's fiction. London: Macmillan Press.

Wertsch, J. V. (2009). Voices of the mind: A sociocultural approach to mediated action. Cambridge: Harvard University Press.

Wille, C. (2016). Spaces and identities in border regions: Politics - media-subjects. Bielefeld: Transcript.

Zanfabro, G. (2017). Gender matters: What is at stake in dealing with children's literature? Trans-, (21). https://doi.org/10.4000/trans.1440

\section{Sources}

COD - Collins Online Dictionary. Retrieved from https://www.collinsdictionary.com/dictionary/english/border

MWOD - Merriam Webster's Online Dictionary. Retrieved from https://www.merriamwebster.com/dictionary/border?src=search-dict-hed

Wilder, L. I. (2003a). By the Shores of Silver Lake. New York: Harper Collins.

Wilder, L. I. (2003b). Farmer Boy. New York: Harper Collins.

Wilder, L. I. (2003c). Little House in the Big Woods. New York: Harper Collins.

Wilder, L. I. (2003d). Little House on the Prairie. New York: Harper Collins.

Wilder, L. I. (2003e). Little Town on the Prairie. New York: Harper Collins.

Wilder, L. I. (2003f). On the Banks of Plum Creek. New York: Harper Collins.

Wilder, L. I. (2003g). The Long Wwinter. New York: Harper Collins. 